\title{
Anabases
}

ANABASES Traditions et réceptions de l'Antiquité

$21 \mid 2015$

Varia

\section{Back to the Archives: Elias Bickerman in the Fonds Louis Robert}

Albert I. Baumgarten

\section{(2) OpenEdition}

1 Journals

Electronic version

URL: http://journals.openedition.org/anabases/5309

DOI: 10.4000/anabases.5309

ISSN: 2256-9421

Publisher

E.R.A.S.M.E.

\section{Printed version}

Date of publication: 1 April 2015

Number of pages: 159-179

ISSN: 1774-4296

\section{Electronic reference}

Albert I. Baumgarten, «Back to the Archives: Elias Bickerman in the Fonds Louis Robert », Anabases

[Online], 21 | 2015, Online since 01 April 2018, connection on 21 October 2019. URL : http:// journals.openedition.org/anabases/5309 ; DOI : 10.4000/anabases.5309

(c) Anabases 


\section{Back to the Archives: Elias Bickerman in the Fonds Louis Robert}

Albert I. BAumgarten

T he Fonds Louis Robert, at the Académie des Inscriptions et Belles-Lettres in Paris, was created by the donation of $\mathrm{M}^{\text {me }}$ Jeanne Robert (I9IO-2002). ${ }^{1} \mathrm{It}$ contains a large collection of material relating to the life and work of Louis Robert (1904-1985), the distinguished French historian of antiquity, the foremost epigraphist of the age, who pioneered the use of historical geography in Classics. ${ }^{2}$ Elias Bickerman (I897-I98I) figures a number of times in the correspondence preserved there, both in letters he wrote to Robert and in letters that Henri Seyrig (I895-1973) wrote to Robert. ${ }^{3}$ There are six letters from Bickerman to Robert, dated March I9, I945, November 23, I945, January 9, I948, April ı2, I948, June I4, I955, and December 27, I965 in the Fonds Louis Robert, while Bickerman is mentioned in

1 On Jeanne Robert as a scholar, both in collaboration with her husband and on her own, see P.Hermann, "Jeanne Robert", Gnomon 75 (2003), p. I9o-ıgi. For a description of the contents of the Fonds Louis Robert, its history and regulations see http://www.aibl.fr/ travaux/antiquite/article/le-fonds-louis-robert. On the circumstances and history of the donation see G. Bowersock, "Louis Robert: la gloire et la joie d'une vie consacrée à l'antiquité grecque", Studi Ellenistici 24 (2010), p. I3-15.

2 On Robert see See Bowersock, "Louis Robert", p. 9-3i.

3 No biography of Seyrig has appeared thus far. Perhaps the recent conference devoted to Seyrig, held on October Io-II, 2013 at the Bibliothèque nationale de France and the Académie des Inscriptions et Belles-Lettres, will begin to fill the lacuna concerning this distinguished scholar, Professor Glen Bowersock is considering authorization of a complete publication of the I58 letters from Seyrig to Robert but has not so far found an appropriate editor with the diverse range of skills required for the task. (Letters of April I, 20I4 and November 25, 2014). 
nine letters from Seyrig to Robert, the first from July i5, I938 and the last from August 8, I965, with the bulk of the letters from the years of World War II and its immediate aftermath. These letters deal almost entirely with academic matters of different sorts, such as proofs of Bickerman's articles, orders for books published on either side of the Atlantic, and reviews of books. My focus in this paper will be on the brief remarks in these letters that concern the relationship between Bickerman, Robert, and Seyrig. However, in order to give the reader a sense of this correspondence, of the typical fuller context in which the little bits and pieces from other letters quoted below appear, I reproduce in full Bickerman's letter to Robert of March I9, I945, the first letter in the series.

Elias J. Bickerman

Ioo West $80^{\text {th }}$ Street $^{4}$

New York 24, N.Y.

Le i9 Mars 1945

Mon cher ami,

Je viens de recevoir votre lettre de 23.II. Je n'ai pas besoin de vous dire comme je suis content. Vous devinez que nous avons souvent pensé à vous et les vôtres, ma femme et moi. Elle est toujours souffrante, une maladie suit l'autre surtout depuis qu'elle a appris que sa mère a été déportée. ${ }^{5}$ La situation alimentaire en France nous enrage, mais la faute en est en partie au gouvernement français qui était plus préoccupé de "haute politique" que des choses terre à terre, et où il y avait trop d'esprit "émigré". Ajoutez les folies administratives: toujours on ne peut pas faire entrer des cigarettes en France. Télégraphiez-moi les médicaments dont vous avez besoin, je vous les ferai parvenir le plus vite possible. Je vous ai envoyé deux colis alimentaires, d'autres suivront. Quelle est l'adresse actuelle d'Is. Lévy? ${ }^{6}$

4 The Bickermans lived on the Upper West Side of Manhattan. This area was favored by European émigrés; it was probably the neighborhood with the most European atmosphere in New York City.

5 Mrs. Bickerman's mother, Toni Bernstein, was “T.B. Deported by the Germans, Ps. 35:I7" to whom the 1947 translation of The Maccabees was dedicated. Even two years later than the letter cited above, in I947, Elias Bickerman and his wife cherished the hope that Toni Bernstein would still turn up alive. She was not "murdered" by the Nazis, or "killed" by them, merely "deported". The verse from Psalms cited in the dedication of The Maccabees supported this slim ray of optimism. See further Baumgarten, Elias Bickerman, p. 45-47.

6 On Lévy's role in Bickerman's career while in Paris see Baumgarten, Elias Bickerman, p. I22 and I27. 
Je vous enverrai les livres demandés, peut-être avec les collections achetées par le gouvernement pour les bibliothèques françaises. Mille fois merci pour des soins donnés à mes livres.

Ayez la bonté de lire les épreuves de mon article dans REg. Il y avait des fautes d'impression; et ajoutez la date: Mai i940, pour expliquer pourquoi je ne cite pas les articles de Fine (AJPh. I940) et de Walbank (JHS I942) etc. ${ }^{7}$ J'ai sous presse un article sur Pol. VII, $9,{ }^{8}$ un autre sur la Seconde Guerre de Macédoine, ${ }^{9}$ et un troisième à propos de Rostovtz. Soc. History of the Hellenistic World. ${ }^{10}$ Vous me manquez énormément pour échanger des idées, demander des renseignements, p. ex. aujourd'hui quand j'écris sur chronologie des Arsacides, d'Attale I, etc. pour Berytus. " Ici, on est pratiquement seul. ${ }^{12}$ À propos, Grégoire ${ }^{13}$ a posé ma candidature à la chaire d'Is. Lévy à Bruxelles, devenue vacante. Parlez-en à Is. Lévy. J'y tiens beaucoup, car, en raison des chinoiseries administratives, Bruxelles est probablement la seule univ. française où je pourrais m'établir. Dussaud ${ }^{14}$ m'écrit qu'il manque de papier pour RHR. Peut être vous (ou lui) pourraient me faire parvenir par Seyrig et ses service mon Ms. laissé pour RHR. ${ }^{15}$ Quand tout sera remis en ordre, je donnerai à Dussaud, s'il y tient, d'autres articles. Chez vous j'ai laissé un article sur Salluste. Pourrait-il paraître dans

7 E.J. Bickerman, "Notes sur Polybe II", in E.J.Bickerman, Religions and Politics in the Hellenistic and Roman Periods, edited by Emilio Gabba and Morton Smith, Comorg85, p. 67 -I84.

8 E.J. Bickerman, "An Oath of Hannibal”, Religions and Politics, p. 255-272.

9 E.J. Bickerman, "Bellum Phillipicum, Some Roman and Greek views concerning the causes of the Second Macedonian War", Religions and Politics, p. 273-286.

10 E.J. Bickerman, "L'européisation de l'Orient classique", Renaissance 2-3 (I944-45), p.38I-392.

11 E.J. Bickerman, "Notes on the Seleucid and Parthian Chronology", Berytus 8 (I943-44), p. $73-83$.

12 Decades later, in the usA, Bickerman could still complain that there were no good professors of ancient history there, no Momiglianos or Roberts (Letter to Gabba, February 22, 1979, Gabba Archives). See Baumgarten, Elias Bickerman, p. I62.

13 Henri Grégoire (I88I-I964), the Belgian historian of the Byzantine period, was at the École libre des hautes études in New York during World War II.

14 René Dussaud (I868-ıg58) found work for Bickerman when he lost his position in Paris after the German invasion. See Baumgarten, Elias Bickerman, p. I33.

15 So far as I can determine this MS was lost. This was not the only piece of Bickerman's work lost during World War II. Bickerman wrote a volume for the series Histoire générale edited by Gustave Glotz, a project mentioned by M. Rostovtzeff in his letter concerning Bickerman to W.L. Westermann of March 29, I939, Baumgarten, Elias Bickerman, p. I29. Writing to Robert on November 23, 1945, Bickerman asked: Pourrais-je vous prier de demander à la famille de Roussel s'ils ont trouvé mon Ms. destiné à l'Hist. Générale de Glotz? Ce serait fâcheux si le Ms. s'égare, comme je n'ai pas gardé une copie. 
ReL ou Rev. de Phil.? ${ }^{16}$ Donnez-moi de nouvelles sur Vajda, ${ }^{17}$ Liber, ${ }^{18}$ Etard, ${ }^{19}$ et saluez

16 The article appeared in REL. See E.J. Bickerman, "La lettre de Mithridate dans les 'Histoires' de Salluste", Religions and Politics, p.287-3og. Mithridates' letter in Sallust was a sensitive matter for Bickerman as it was one of the principal topics of his Habilitationsschrift in Berlin in I929, which was severely criticized by its readers. See Baumgarten, Elias Bickerman, p.86-95. However, it was not only the Habilitationsschrift that was found wanting. According to F.Solmsen, "Classical Scholarship in Berlin between the Wars", Greek, Roman and Byzantine Studies 3o (I989), p.135 when Bickerman spoke at the Probevorlesung on "Books and Battles of the Maccabees", Wilamowitz denounced the source on which much of Bickerman's presentation was based, crushing and demolishing Bickerman, declaring that "one should absolutely not rely on Malalas". Thanks to the kindness of Prof. Klaus Harloff of Berlin (letter of March 28, 2014), I learned more about Bickerman's disastrous first Probevorlesung on July 22, I929, as recounted by Ludwig Deubner (1877-1946), a member of the commission appointed to examine Bickerman's Habilitationsschrift, in his diary entry for July 22, I929:

Die Habilitation Bickermanns endete mit einem Durchfall. Die Darbietung des Vortrages war sehr schwach + wenig klar. Wilcken versuchte ihn zu halten +Norden sekundierte (natürlich: weil es ein Jude war), + auch Oncken stimmte für Durchlassen, doch Ed. Meyer, Wilam., ich, Mazeks, Brachmann + Marckwardt waren dagegen. Der Mann ist trotz aller Gelehrsamkeit + Gescheitheit doch mehr Journalist.

17 Georges Vajda (I908-I98I), a specialist in Semitic languages, taught at the Sorbonne.

18 Grand-Rabbin Maurice Liber (I884-I956) taught Jewish Studies at the École pratique des hautes études, focusing on Rabbinic Literature. Liber and Bickerman agreed in their anti-Zionism, as Liber was convinced that emancipation had resolved the national question for the Jews. Liber and Bickerman might have also collaborated as part of Liber's efforts to help refugees from Nazi Germany resettle in France. On Liber see G. VAJDA, "Le Grand Rabbin Maurice Liber (I3 Septembre I884-23 Novembre ig56)", Revue des Études Juives i5 (ig56), p.5-7. On Bickerman's anti-Zionism see Baumgarten, Elias Bickerman, p. 35; 53-55.

19 Perhaps Madeleine Étard (I897-?), a translator of Russian works into French, among others I. Ehrenbourg, Duhamel, Gide, Malraux, Mauriac, Morands, Romains, Unamuno, vus par un écrivain d'URss, Paris I934. She translated other Russian authors, such as A. Grabar, L'Église de Bö̈ana, architecture-peinture, Paris I924. I am far from certain of this identification: all others in this part of Bickerman's letter taught at institutions of higher learning in France, Paris in particular, during Bickerman's years there. As such, Robert would also have also known them. Yet, I found no proof that Madeleine Étard occupied such a position. If Bickerman knew Étard from the Russian émigré community, how would Robert have known her? 
de ma part Palanque, qui était très convenable à Aix. ${ }^{20}$ Où est Fatzfeld? ${ }^{21}$ Sauvaget? ${ }^{22}$ Mais j'espère d'avoir de nouvelles par Seyrig quand il va revenir. Je vous écris en hâte, car demain une jeune fille du Secrétariat de l'École Libre va partir pour Paris, et elle prend la lettre.

P.S. Vos livres étaient "recensés" dans JHs, pendant la guerre. Par Tod et Woodward. Celui-ci vous reproche d'avoir oublié quelques inscr. de Sparte. Tod est simplement enchanté.

(Handwritten)

Votre ami E. Bikerman

Ma femme me téléphone priant de vous parvenir ses salutations et ses vœux sympathiques pour la santé de Mme Robert et de Mme votre mère. ${ }^{23}$

\section{II}

The documents at the Fonds Louis Robert concerning Bickerman allow a renewed and deeper insight into the two most influential and magisterial works that appeared in his lifetime: ${ }^{24}$ Der Gott der Makkabäer in 1937 and Institutions des Séleucides in I938. The reflections on these two works stimulated by these archival finds also permit an important confirmation of the interplay of past and present, life experience and political commitment, in shaping a historian's interpretation of the past.

In both Der Gott der Makkabäer and Institutions des Séleucides Bickerman displayed that special quality that made his work so distinctive. As noted by Anthony Grafton, "Given random series of official documents, Bickerman could reconstruct the bureaucracies that had produced them with an almost magical

20 Jean-Rémy Palanque (I898-I988) was Professor of Ancient History at Aix-en-Provence. Palanque assisted many of those in trouble during World War II, for which he was awarded the Medal of the Resistance in 1945. Bickerman, who spent February to June I942 under house arrest (residence forcée) in Aix, was one of those helped by Palanque. See Baumgarten, Elias Bickerman, p. I37, 323. On Palanque see further J.Pouilloux, “Allocution à l'occasion du décès de M.Jean-Rémy Palanque, académicien libre", $C R A I$ I32 (I988), p. 428-43i.

21 Bickerman intended Jean Hatzfeld (1880-1947), an archeologist and Hellenist who published on the history of ancient Greece.

22 Jean Sauvaget was an orientalist. See F.E. DAy, "Jean Sauvaget (I9oI-I95o)", Ars Orientalia I (I954), p. 259-262.

23 I have corrected obvious errors in Bickerman's French. See Baumgarten, Elias Bickerman, p. 245, n. 20.

24 The Jews in the Greek Age appeared posthumously. 
precision... Bickerman, it seems, had a kind of occult natural ability to see texts as they were and to recreate the circumstances in which they were created. ${ }^{25}$ "Nevertheless, despite the fact that Der Gott der Makkabäer and Institutions des Séleucides were published at virtually the same time and that both drew heavily on his analysis of I and II Macc, Bickerman's attitude towards the past as expressed in the Prefaces of these works was radically different. While one was open-mindedly tentative, the other was much more determinedly dogmatic. I begin with Institutions des Séleucides.

\section{III}

Institutions des Séleucides was written in close collaboration with Bickerman's dear personal friend, Louis Robert. Indeed, the archival documents that are the stimulus for this article attest to the very close relationship between the Bickermans and the Roberts, as couples. Thus, although Bickerman did not share personal information about himself, even with someone as close as Michael Rostovtzeff (1870I952), his St. Petersburg teacher and mentor through difficult years in Germany and Nazi France, ${ }^{26}$ in the letter quoted above he noted the troubles his wife, Anita Suzanne Bickerman (I9I3-I998), was undergoing in New York: ma femme... est toujours souffrante, une maladie suit l'autre, surtout depuis qu'elle a appris que sa mère a été déportée. Several years later, in a letter of January 9, I948, he explained that his wife would soon be travelling to Nice: elle a un besoin urgent du repos, qu'on ne trouve pas ici. Pour vivre à N.Y. il faut avoir des nerfs et la santé de fer. ${ }^{27} \mathrm{As}$ one further indication of the deep familial connection between the two couples, Bickerman added a handwritten postscript to the letter quoted above: ma femme me téléphone priant de vous parvenir ses salutations et ses voux sympathiques pour la santé de Mme Robert et de Mme votre mère. In a handwritten postscript to his letter to Robert of November 23, I945 Bickerman wrote: nous étions (i.e. he and his

25 A. Grafton, "The Bible Scholar who did not know Hebrew", The Jewish Review of Books 3 (Fall 20I0), p. 37.

26 Rostovtzeff noted that when he corresponded with Bickerman, "he never speaks about his family affairs". Rostovtzeff to Johnson, October 4, I940, Rostovtzeff Archive = G. Bongard-Levin, Skifskii Roman, Moscow i997, \#9. Thus, while Rostovtzeff knew that Bickerman had no children when he had last seen him in 1937 , he did not know if any had been born between then and when he wrote this letter in I940.

27 I presume that Anita Suzanne Bickerman travelled to Nice to be with her father, Georges Bernstein, who visited his daughter in NY in November I947, Baumgarten, Elias Bickerman, p.47. On the Bickerman couple in the ig5os and their eventual separation and divorce see ibid., p. 22-23. For a photograph of Elias and Anita Suzanne Bickerman from 1945 see ibid., p. 318, plate 3. 
wife) très touchés du post-scriptum de Madame Robert dans votre lettre. Finally, in a handwritten postscript to his letter of June 14, I955, Bickerman sent his regards (now in his name only) to $\mathrm{M}^{\mathrm{me}}$ Robert and to Louis Robert's mother. ${ }^{28}$

In practical terms, Bickerman asked Robert to speak with Is. Lévy of Brussels concerning Henri Grégoire's suggestion that Bickerman replace Lévy at Brussels. Bickerman had great hopes for the outcome there, because, as he wrote in the letter cited above, en raison des chinoiseries administratives, Bruxelles est probablement la seule univ. française où je pourrais m'établir.

Food, medicine, and other necessities were then in short supply in Europe, a circumstance that Bickerman blamed on the policies of the French government in the letter of March I9, I945, quoted above. In that letter, Bickerman offered to send medicines, and had already sent two food parcels to the Roberts, with more to follow. Food and other supplies - a bottle of oil for $\mathbf{M}^{\mathrm{me}}$ Robert, charcuterie and cheese - were noted in Bickerman's letter of November 23, 1945, in which Bickerman regretted that he had not sent the Roberts an electric hearer; if he first sent it now it would arrive in the Spring. One must note that Bickerman went to all this trouble and expense despite the fact that his own academic situation was then most uncertain and his financial circumstances not that good. ${ }^{29}$ Another matter of concern in these letters from the years immediately after the war was Bickerman's books, left behind in France when he escaped for the usA, which Robert was arranging shipping to New York (letters of January 9, I948 and April ı2, I948).

These greetings to Louis Robert's wife, formerly $\mathbf{M}^{\text {lle }}$ J.Vanseveren, have a specific context. The Annuaire of the École Pratique records information about Bickerman's courses there: In I936-37 Bickerman gave a course on Seleucid and Roman texts preserved by Josephus in light of papyri and inscriptions. $\mathbf{M}^{\text {lle }} \mathrm{J}$. Vanseveren was noted as one of the auditeurs reguliers, Annuaire, I936-37, p.46. In Bickerman's courses in I937-38 and $1938-39$ the Annuaire noted that $\mathrm{M}^{\mathrm{Ile}} \mathrm{J}$.Vanseveren a pris une parte active aux discussions. Apparently, Louis Robert, who already taught J.Vanseveren in I935, recommended that his student and future bride participate in Bickerman's courses. This would be one more indication of Robert's high regard for Bickerman, but the three years $M^{\text {me }}$ Robert spent as Bickerman's student provided an additional foundation for a direct personal relationship between the teacher and his former student.

The greetings to the elder $\mathbf{M}^{\mathrm{me}}$ Robert are further attestations to the fact that the Bickermans were frequent guests at the home of the Roberts and of the close connection between the Roberts and Bickermans as families. Robert's mother lived with her son and daughter-in-law, and Louis Robert was very attached to her. Her passing was so disturbing to Robert that his annual publication of Bulletin Épigraphique did not appear in the year following her death. Any "regular" at the home of the Roberts would have met the elder $\mathrm{M}^{\mathrm{me}}$ Robert and been aware of her importance for her son (Glen Bowersock, letter of November 26, 2013). 
In scholarly terms, Robert shared Bickerman's unusual ability for turning the smallest details concerning the Greco-Roman world into the starting points of elaborate and wide-ranging reconstructions of ancient life and times. ${ }^{30}$ Bickerman's evaluation of Robert's scholarship could not have been higher. In his letter to Robert quoted above, Bickerman wrote: vous me manquez énormément pour échanger des idées, demander des renseignements, p. ex. aujourd'hui quand j'écris sur chronologie des Arsacides, d'Attale I, etc. pour Berytus. Ici on est pratiquement seul. A decade later, on June I4, I955, Bickerman wrote to Robert the following "rebuke":

Je vois que vous allez repartir encore une fois pour la Turquie. J'admire votre énergie indomptable (et la patience de M-me. L.R.), mais, permettez moi le dire, je hésite d'applaudir. En travaillant chaque été, après votre effort prodigieux et généreux de l'année scolaire, vous vous ruinez. D'ailleurs, il ne manque pas de fouilleurs, mais vous le savez vous-même - L.R. est unique et le temps dépensé pour fouiller telle ruine pourrait servir à rédiger un volume que personne pourrait nous donner sauf L.R. Oui, je sais que les conseils ne plaisent qu'à ceux qui les donnent. Mais vous connaissez mon affection et admiration reconnaissante pour vous. D'ailleurs, je viens d'être gravement souffrant (une sorte de pneumonie), la première maladie sérieuse depuis 35 ans, ${ }^{31}$ et telle expérience vous apprend à penser à la santé de ceux qu'on aime.

At the end of the same letter, Bickerman complained about one of the students he had "inherited" from W.L. Westermann (I873-r954) at Columbia. Bickerman then added: sij'ai un bon élève, je le ferai aller à l'EHE d'apprendre le métier chez L.R. ${ }^{32}$ I heard similar high praise of Robert in Bickerman's class.

Robert's contribution to Institutions des Séleucides was substantial. As Bickerman wrote in the Preface: je ne pourrais taire sans ingratitude mon obligation particulière envers mon ami Louis Robert, qui a pris la peine de lire tout le manuscrit et a revu de plus les épreuves de cette étude. Le présent livre lui doit beaucoup de suggestions et corrections. ${ }^{33}$ When the book appeared Robert wrote to Bickerman thanking him for the specially prepared copy that Bickerman had sent, bound in the same special binding, with Robert's initials, as other books in

30 For Bowersock's evaluation of Robert's contributions see above, n. 2.

31 Bickerman was seriously ill during the Civil War in Russia. See Baumgarten, Elias Bickerman, p.38.

32 Although Robert was appointed in I939 at the Collège de France (See BowErsock, "Louis Robert", p. II), he continued to teach at the École pratique des hautes études, as did other colleagues.

33 E. Bikerman, Institutions des Séleucides, Paris ig38, p. 2. 
Robert's library. ${ }^{34}$ Bickerman saved this letter, along with two others, from Franz Cumont (I868-ı947) and André Piganiol (I883-I968), in his personal copy of Institutions des Séleucides. ${ }^{35}$ Robert noted that Bickerman's academic contributions and his approach to scholarship were a source of intellectual enjoyment and one of the true pleasures of his life:

Samedi, I2 mars

Cher ami,

laissez-moi vous dire que j'ai été véritablement ému en ayant cette surprise de cette belle reliure, faite à mon goût, sur le modèle de mes livres préférés. J'ai été si touché de cette délicate attention, et d'y trouver mes initiales comme sur les livres de ma bibliothèque. Comment avez-vous pu le faire relier en si peu de temps? Quelle surprise!

Je ne vous parlerai pas du contenu; il nous est trop familier. Que ce me soit du moins l'occasion de vous dire combien vos travaux et votre tournure d'esprit me sont une jouissance intellectuelle, vraiment un des plaisirs de ma vie.

Votre ami,

Louis Robert

In the preface to the volume, while Bickerman stressed that this was a new book, of a type that had not been attempted before, he also dwelt at length on its limitations due to the nature of the available evidence, scattered in numerous sources that no one had bothered to systematically collect. Furthermore, not enough of the Seleucid cities and villages founded in the East had been excavated. It was therefore impossible to discuss the nature of Seleucid colonization. Only two or three documents yielded information about Seleucid law. Bickerman therefore chose not to fill the missing gaps with Egyptian, Greek, or Parthian parallels, but preferred instead to confess our (or just his) ignorance. He therefore narrowed the focus of the book to topics on which he felt more certain he could say something, such as the king, his court, army, treasury, administrative organization, coinage, and the religion of the dynasty. As this list indicates, "narrow" as the focus was, the book was still a vast and monumental undertaking.

Bickerman was aware of the tentative nature of what he had written. Excavations such as those conducted by Rostovtzeff and Cumont at Dura Europos were revealing new aspects of life in the East. A scholar needed to be open-minded and willing to change his/her mind as this new information became available:

34 I have not found the copy of Institutions des Séleucides that Bickerman sent Robert. Unfortunately, it is not in the Fonds Louis Robert.

35 Bickerman Archive, Jewish Theological Seminary, Box 4, folder I4. I thank Professor Corinne Bonnet of Toulouse University for her help in transcribing these three letters. 
Demain ou après-demain de nouveaux documents, sortis du sol de l'Asie, combleront des lacunes, corrigent des erreurs de mon livre. Il importe fort peu même pour l'auteur que les témoignages nouveaux confirment ou détruisent des affirmations et des hypothèses de cet ouvrage. Ce à quoi je tiens, c'est à aider à mieux comprendre les textes connus comme les textes qui vont être découverts. Finis libri non finis quaerendi. ${ }^{36}$

Bickerman remained aware of the need for revision in the light of new information until the end of his life. In a rough draft of a preface prepared for the Russian translation of Institutions des Séleucides, which appeared after his death, in I985, he explained that he felt little need to change what he had written in most of the book. However, the chapter on Seleucid coinage needed extensive revision in light of the work of numerous scholars - his friends Newell, Seyrig, Schlumberger, Boehringer, G. Le Rider, Morkholm, and Louis Robert. He added:

J'espère qu'un de mes jeunes lecteurs se mettre à la tâche de récrire mon esquisse. Des corrigenda aussi qu'une bibliographie sélective ajoutées à la traduction permettons le lecteur russe se tenir au courant de l'état présent des recherches sur l'État séleucide. ${ }^{37}$

The tentative nature of the work and the need to remain open minded was evident to Franz Cumont (I868-I947) in his letter thanking Bickerman for a copy of Institutions des Séleucides, preserved in Bickerman's personal copy. While praising the book, Cumont offered a number of suggestions and corrections that might be included in a second edition. I cite only the opening paragraph, as the specific suggestions are of less importance for the purposes of my argument in this paper: ${ }^{38}$

Rome, 7 Mai I938.

Cher monsieur Bikerman,

Vous m'avez à la fois fait un vif plaisir et rendu un grand service en m'envoyant votre volume et je vous remercie sincèrement de ce don précieux. Faut-il vous faire l'éloge de votre ouvrage? Vous avez écrit un chapitre nouveau de l'histoire de l'hellénisme

36 Bikerman, Institutions des Séleucides, p.2.

37 Bickerman Archive, Jewish Theological Seminary, Box 6, folder 4. See the discussion of this preface in Baumgarten, Elias Bickerman, p. 244-245. For revisions now necessary in Institutions des Séleucides due to new information see J.MA, "Relire les Institutions des Séleucides de Bikerman", in S. BENoIst (ed.), Rome, a City and its Empire in Perspective: The Impact of the Roman World through Fergus Millar's Research, Leiden - Boston 20I2, p. $59-84$.

38 The three letters Bickerman preserved in his copy of Institutions des Séleucides merit a comprehensive and independent assessment of their own. Professor Bonnet and I plan to publish a paper on them. 
et méritez la gratitude de tous ceux qui s'intéressent aux institutions de l'antiquité. Je suis certain que ce livre, indispensable à tous les érudits, s'épuisera rapidement et plutôt que de le louer sans profit pour vous, j'aime mieux vous envoyer quelques notules, griffonnées au cours d'une lecture trop rapide, en vue d'une deuxième édition.

\section{IV}

As noted at the outset, Bickerman's approach to the past was very different in Der Gott der Makkabäer. This work was written in close collaboration with Bickerman's dear friend from Berlin, Hans Lewy. ${ }^{39}$ Christians and Jews might ponder the meaning of the Maccabean persecutions and ask why God allowed His faithful to die in allegiance to His truth. The Jewish answer was that the persecution was a punishment sent by God, for which the blood of the martyrs was the price to be paid for salvation, and the liberation from the oppression was a result of the repentance of the oppressed: Das Blut der Märtyrer der Preis der Erlösung und die Befreiung aus der Not eine Folge der inneren Umkehr der Bedrängten. ${ }^{40}$

However, the historian dare not ask questions of that sort: theodicy was not a historian's concern. The only judgment allowed a historian was to inquire whether the interpretation of an event, with which a seer or wise man had to contend, corresponded to the actual course of events. The aim of the book was thus historical, Die Zielsetzung dieses Buches ist eine rein historische - "to determine the sequence of events we usually call the persecution of Antiochus and to make this series of

See A.I. Baumgarten, "Elias Bickerman and Hans (Yohanan) Lewy: The story of a friendship", Anabases i3 (201г), p. 95-II8, esp.p. 96-97.

40 E. Bickermann, Der Gott der Makkabäer: Untersuchungen über Sinn und Ursprung der makkabäischen Erhebung, Berlin I937, p.7. Compare E. Bickerman, The God of the Maccabees, Studies in the Meaning and Origin of the Maccabean Revolt, translated by H. Moenring, Leiden I979, p. I = Studies in Jewish and Christian History, A New Edition in English including The God of the Maccabees, introduced by Martin Hengel, edited by Amram Tropper, Leiden 2007, p. Io33.

Bickerman was extremely unhappy with Moehring's translation. The notes were omitted, which allowed the reader no appreciation of the brilliance of the interpretation of the evidence in making the argument of the book. In an undated postcard to Gabba, postmarked February I8, I980, Bickerman complained that the English version of God of the Maccabees was awful: Brill did not allow extensive additions and then paid no royalties. He concluded that the book was useful only to those who cannot read German, that is, to Americans, and that the publication was a "bastard of my productivity". See Baumgarten, Elias Bickerman, p. 162. 
events comprehensible. ${ }^{41}$ " The investigation originated in a philological analysis of the books of Maccabees and was intended as a preliminary study for a full-scale commentary on these sources, which Bickerman was supposed to write. ${ }^{42}$ Nothing was tentative here, or subject to revision in light of future discoveries. ${ }^{43}$ As is well known, Bickerman concluded that the initiative for the persecution came not from without but from within, from a Jewish group that included the leading members of society, that intended to reform Judaism, without completely rejecting the God of the Fathers or without total disloyalty to Zion. The Maccabees saved the Jews (and ultimately, mankind) from this reform and led the people back to the God of Abraham, Isaac and Jacob. History thus confirmed theology, and Bickerman's language now echoed explicitly the theological explanation offered earlier: Die Geschichte bestätigt somit die Theologie. Nicht von aussen, sondern von innen kommt das Unglück, aber auch die Rettung, deren Voraussetzung die Umkehr ist. ${ }^{44}$ He ended by quoting Ps. Iо6:43-46:

He saved them time and time again, but they were deliberately rebellious, and so they were brought low by their iniquity. When He saw that they were in distress, when He heard their cry, He was mindful of His covenant and in His great faithfulness relented. He made their captors kindly disposed towards them.

The confirmation of theodicy offered by history, despite the earlier disclaimer that questions of theodicy were not part of the historian's task, is an indication that, unlike the circumstances involved in writing Institutions des Séleucides, something more than historical inquiry was at stake in Bickerman's investigation of the persecutions and the explanations he offered for these events. There was something determinedly dogmatic about the thesis Bickerman offered: it mattered to him in

41 Gott derMakkabäer, p. 7 = God of the Maccabees, p. I = Studies, ANew Edition in English, p. I033.

42 This commentary never appeared. For an account of Bickerman's invitation to write these commentaries see God of the Maccabees, p.xi-xii = Studies, A New Edition in English, p. I029-I03o, and Baumgarten, Elias Bickerman, p. 35 o.

43 When Bickerman's interpretation was challenged, as did I. HeInEManN, "Wer veranlasste den Glaubenszwang der Makkabäerzeit?",Monatsschrift für Geschichte und Wissenschaft des Judentums 82 (I938), p. I45-I72, Bickerman responded to the critique by admitting its force and some of its valid points, yet nevertheless maintained his allegiance to the basic thesis argued in Der Gott der Makkabäer. The need to restate and revise arguments made in Der Gott der Makkabäer in light of Heinemann's criticism was a major impetus behind The Jews in the Greek Age. See A.I.BAumgarten, "Bibliographical Note", in E.J. Bickerman, The Jews in the Greek Age, Cambridge, MA I988, p.3og-327.

44 Gott der Makkabäer, p.8. Cf. God of the Maccabees, p.2 = Studies, A New Edition in English, p. I034. 
a deep personal way. This conclusion is made even more definite by the end of the book, a declaration of faith and a clear call for martyrdom, if necessary, in face of the impending doom of European Jewry in the Nazi era:

For the deeds of the Maccabeans are worth remembering forever, only because they resulted in the survival of monotheism. Through the blood witness of the martyrs, through the service in the rededicated temple the one truth was saved which for mankind during its wanderings of a thousand years, it has found unchangeable and eternal. Man has been deceived and disappointed by innumerable alleged truths - but never by the one truth of the uniqueness of God. Thus, those men and women and children who sacrificed their lives during the persecution under Epiphanes in order to remain faithful to the Eternal One, remain forever and for all peoples examples of true heroism. "May men learn from them to die for the truth" says Augustine (P.L. 38, I379). ${ }^{45}$

Nevertheless, in the end, Bickerman's case concerning the persecutions of Antiochus IV must be judged and was evaluated by his peers as history, not theodicy. As such, as I have argued elsewhere, it was found wanting, and new evidence found since Bickerman wrote may undermine his case further. ${ }^{46}$ This outcome, as I argued, was most unlike that of many of Bickerman's other contributions, which were almost immediately recognized as masterly conclusions. It was not without reason that Arnaldo Momigliano, no mean scholar himself, wrote that "I never disagree lightly with Elias Bickerman," ${ }^{47}$ yet numerous scholars expressed reservations about Bickerman's explanation of the persecutions and offered interpretations of their own - for better or worse - for these events, and the list of these scholars includes Momigliano. ${ }^{48}$ Perhaps the only scholar to fully embrace Bicker-

45 Gott der Makkabäer, p.139 = God of the Maccabees, p. 92 =Studies, A New Edition in English, p.in26. As I argued in Baumgarten, Elias Bickerman, p.249, the quote from Augustine was a brilliant way to avoid complications with Nazi censorship. How could a censor object to Augustine?

46 See D. Gera, "Heliodoros, Olympiodoros, and the Temples of Koilê Syria and Phoinikê", Zeitschrift für Papyrologie und Epigraphik ı69 (2009), p. І25-ı55; C.P. Jones, "The Inscription from Tel Maresha for Olympiodoros", Zeitschrift für Papyrologie und Epigraphik I7I (2009), p. IOо-I04.

47 A. Momigliano, Alien Wisdom - The Limits of Hellenization, New York i975, p.91. On Momigliano and Bickerman see Baumgarten, Elias Bickerman, p. I93-204.

48 The list of those who dissented from Bickerman's interpretation or offered interpretations of their own of the evidence is very long. For Heinemann's dissent 
man's views and attempt to extend them further was Martin Hengel (I926-2009), of Tübingen University. ${ }^{49}$ However, the response to Hengel's massive volumes has generated further responses to Bickerman's initial suggestion, and these contributions are sometimes highly critical of Hengel for following in Bickerman's path. ${ }^{50}$ Viewed in the light of the overwhelmingly favorable reception of his other publications, the numerous scholars who dissented from Bickerman and offered interpretations of their own did not do this as an act of eccentric willfulness or academic vengeance. They did so on the basis of their understanding of the evidence and their cumulative response deserves respect. I therefore concluded that Der Gott derMakkabäer was a "failure. ${ }^{51 "}$

\section{VI}

But why did this happen? Why was Bickerman so much less convincing on the persecutions of Antiochus IV? His comment cited from the preface to Der Gott der Makkabäer (above, I70), about history confirming theodicy, the dogmatic certainty exhibited in the preface to Der Gott der Makkabäer as opposed to Institutions des Séleucides, all suggest that something deeply personal and a matter of intense individual commitment was at stake in Der Gott der Makkabäer. This book, as Grafton

and its consequences see above, n. 43. For Momigliano's dissent See A.Momigliano, "Review, M. Hengel, Judentum und Hellenismus", Journal of Theological Studies 2I (1970), p. I49-153, and then at greater length in Momigliano, Alien Wisdom, p. Io6-iI2.

49 M. Hengel, Judaism and Hellenism, translated by J. Bowden, Philadelphia I974. Hengel turned Bickerman into his intellectual master, who set the agenda for much of his scholarly career; see M. Hengel, "Erinnerungen an einen grossen Althistoriker aus St. Petersburg", Hyperboreus ıо (2004), p. I92-194=Studies, A New Edition in English, p.xlix-lii.

50 See for example H. CANcIK, "Besp.Martin Hengel, Judentum und Hellenismus", Theologische Quartalschrift I5I (197I), p.36o-362; F. MiLlar, "The Background to the Maccabean Revolution: Reflections on Martin Hengel's Judaism and Hellenism", Journal of Jewish Studies 29 (I978), p. I-2I; M. STERN, "Review of Hengel, Judaism and Hellenism", Studies in Jewish History: The Second Temple Period, Jerusalem I99I, p.578-586 [Hebrew]; ID., "Judaism and Hellenism in the Land of Israel in the Third and Second Centuries BCE", Studies in Jewish History, p. 3-2I [Hebrew].

51 Baumgarten, "Elias Bickerman on the Hellenizing Reformers", p.ı49-179. Compare U.Rappaport, "Elias Bickerman: Historian of Hellenization and the Decrees of Antiochus", Cathedra I49 (5774), p. I43-I52 [Hebrew]. Rappaport is unwilling to deem Der Gott der Makkabäer a failure in any sense, despite the fact that many scholars (including Rappaport himself) dissented from some of its major conclusions, because the book was so stimulating, original, and provocative. For a balanced attempt to consider the diverse aspects of Gott der Makkabäer see the conclusion of this article. 
characterized it, was "magnificently polemical" in the service of passionate convictions. ${ }^{52}$ This allegiance, not necessarily shared by others, I suggested, motivated Bickerman to propose an explanation that was far less successful than his other contributions in convincing other scholars.

I therefore took advantage of the approach widely accepted among students of historiography of looking to the scholar's life experiences and ideological preferences as a key to understanding the scholarship. ${ }^{53}$ I should add that indicating a historian's source(s) of inspiration remains an entirely separate question. The objective of research to indicate a historian's source(s) of inspiration is to understand how and why a particular historian came to offer a specific interpretation, no more but no less. This sort of investigation neither detracts nor adds to the degree to which an argument based on the evidence is convincing; it neither validates nor invalidates it. ${ }^{54}$

Bickerman himself appreciated the value of this sort of analysis. While he sought to avoid what he called the "Crocean heresy", that all history is history of the present, Bickerman conceded that the past created by any society is a social construct, a product of the time and place of that past's creation, constantly modified to meet a society's changing needs. Like gravity, Plato's Republic has remained the same, but our understanding of that classic over time differs as a result of new experiences and observations. So too the past. Accordingly, for Bickerman, absolute objectivity was impossible: since the historian was part of the history he or she created, history was subject to the forces of the time and place in which it was being fabricated. History was not physics. Moreover, history must reckon with accidents, events that can never be explained (the "law of unintended consequences"). For that reason (and against the Marxists) history had little predictive value. It may teach how to avoid mistakes; it may be philosophy by examples ${ }^{55}$ but the

52 Grafton, "The Bible Scholar", p.37. See also K. Bringmann, "Elias Bickerman und der 'Gott der Makkabäer', Ein Historiker zwischen Theodizee und Geschichtswissenschaft”, Trumah, I7 (2007), p.5-7. As Bringmann concluded there, concerning Der Gott der Makkabäer: In ihr steckt ein persönliches Glaubensbekenntnis.

53 See E.H. CARR, What is History?, New York ig64. This book generated much discussion. For one important critique of Carr's approach see J.H.Hexter, Doing History, London I97I, p. 77-ı6.

54 For a full discussion of Rappaport's critique of my approach in analyzing Bickerman's life and works (above, n. 5i) and my response see A.I.Baumgarten, "Elias Bickerman's Gott der Makkabäer," [Hebrew] to appear soon in Cathedra.

55 The role of history as experimental politics, and therefore as the best teacher of politics, was a key element in the thought of Joseph de Maistre. See for example, J. DE Maistre, The Works of Joseph de Maistre selected, translated and with an Introduction by J.Lively, New York ig65, p. II4. 
complexities of human experience are such that historians must be satisfied if they can understand events. A full account of causality was beyond possibility. The historian's work should be for knowledge for its own sake and should not be mingled with contingency. ${ }^{56}$ Or, as Bickerman wrote to Judah Goldin, responding to Goldin's comments on the Bickerman-Smith volume, "the lessons of history are neglected because the honest historians warn the reader of the equivocal nature of their results. ${ }^{57 "}$

While Bickerman himself connected between the work of other historians and their life experience or commitments, he did not want this sort of analysis offered on his own work. It may be that he ordered his personal papers destroyed in order to make it difficult to find the connections between his life and scholarship. ${ }^{58}$ Nevertheless, Bickerman cannot be an exception to the rule. As he himself insisted, one must read the Bible by the same standards and methods as one reads Tacitus and Livy. $^{59}$

It was in this spirit, but contrary to Bickerman's wishes, that I noted Bickerman's comparison of the ancient extreme Hellenizers of Jerusalem to leaders of the Jewish reform movement in Germany in the nineteenth century and its similarity to views expressed by Samson Raphael Hirsch (I808-I888), the father of $19^{\text {th }}$ century German Jewish neo-Orthodoxy. ${ }^{60} \mathrm{I}$ added two other sources of inspiration of Bickerman's thesis that he did not acknowledge explicitly: (I) the template for his thesis provided by the actions of enlightened Jews asking the Tsarist government to reform Jewish education in the I840s, and to impose that reform on the unenlightened and backward mass of Russian Jews, an episode with which Elias Bickerman should have been very familiar; ${ }^{61}$ (2) the anti-Bolshevik activity of the Patriotic Union of Russian Jews Abroad, of which Elias Bickerman's father, Joseph Bikerman (February I5, I867 (os) - January 4, I942) was the central figure and in whose activities Elias participated during his years in Berlin. The Patriotic Union supported the Whites in the Russian Civil War. The organization was devoted to defen-

56 Bickerman to Raditsa, November 23, I973, Raditsa Archive.

Bickerman set forth his understanding of the matter in a chapter entitled "Why History?", in E. J. Bickerman, M. Smith, The Ancient History of Western Civilization, New York I976, p. I-9. See further Baumgarten, Elias Bickerman, p. 8o-82.

57 Bickerman to Goldin, March 24, I976, responding to Goldin to Bickerman, March 2I, I976, both in Judah Goldin Files.

58 Baumgarten, Elias Bickerman, p. 25-3o.

59 Baumgarten, Elias Bickerman, p.vi, and 172. This was Bickerman's revision of the principle stated by Spinoza, Tract. Theol. Pol. 7.6: dico methodum interpretandi Scripturam haud differe a methodo interpretandi naturam.

60 Baumgarten, "Elias Bickerman on the Hellenizing Reformers", p. I62-I69.

61 Baumgarten, "Russian-Jewish Ideas in German Dress". 
ding the Jews against the charge of the "Kommikike" conspiracy, that all Jews were Bolsheviks (or that all Bolsheviks were Jews). The members of the Patriotic Union were penitent patriots, determined to demonstrate their loyalty to the monarchy and their hatred of the Bolsheviks. ${ }^{62}$ In the end, Joseph Bikerman and his few associates in the "Patriotic Union" expressed an extreme minority view. They were not only considered mad (or worse) by other émigré Jews, such as S.Dubnow (I86oI94I), but their protestations of Russian identity and loyalty were rejected by other Russians, who refused to accept them as their own. ${ }^{63}$ What is important for our purposes is that Jewish communists were the worst of all traitors in the eyes of Joseph Bikerman and the Patriotic Union.

I found at least a hint that Elias Bickerman had collaborated with his father in working out his interpretation of the persecutions of Antiochus IV in his father's public talk in Berlin, delivered on December I2, I929 on Chanukah - a topic far outside the range of Joseph Bikerman's interests and public activity, but precisely in those of his son Elias, and at a time when Elias Bickerman was publishing his first essays on the Maccabees. ${ }^{64}$ I suggested that their hatred of the Jewish communists, as traitors from within, was in the back of their minds (if not closer to front and center) when Elias Bickerman saw the ancient Jewish Hellenizers in Jerusalem as the instigators and the real culprits of the persecutions. When Elias Bickerman concluded the preface of Der Gott der Makkabäer with the remark that: "It is not from without, but from within, that misfortune comes: but also salvation, which is conditioned upon repentance", I wondered whether he was thinking of the campaign of the Patriotic Union as the contemporary example of penitence and of their efforts as leading to salvation from the Bolshevik threat in the here and now. ${ }^{65}$ In sum, I proposed that the contemporary loyalties of Elias Bickerman and

62 The "Patriotic Union" held a rosy view of pre-revolutionary Russia but was not necessarily monarchist. Thus, D.S.Pasmanik (I869-I93o) concluded his contribution to the Russian-German "Patriotic Union" volumes (D.S.PAsmanik, "Was erstreben wir eigentlich?", in J. M. Bickermann [ed.], Die Umwälzung in Russland und das Schicksal der russischen Juden, Ein Sammelwerk, aus dem Russischen übertragen, Berlin I925, p. 2IO-2II) by indicating that it mattered little to him whether a republican president or a Romanov monarch presided over the corpse of Bolshevik Russia. What mattered, as Peter Struve had remarked, was that Bolshevik rule end, not who buried it. Nevertheless, since the "Patriotic Union" supported the White Army, the conclusion that the group was monarchist was virtually inevitable.

63 O. Budnitskir. Russian Jews Between the Reds and the Whites, I9I7-1920, translated by T. J.Portice, Philadelphia 20I2, p.412-413.

64 Baumgarten, Elias Bickerman, p. 263. Unfortunately I only found an announcement of the talk and of its title, but no summary of what Joseph Bikerman said.

65 Baumgarten, "Elias Bickerman on the Hellenizing Reformers", p. I69-I77. 
his father were were so deeply embedded and so idiosyncratic that they overwhelmed Bickerman's usual caution and determination to remain open-minded about his conclusions, as exhibited in Institutions des Séleucides. ${ }^{66}$ If I am correct and these commitments helped provide the background for Elias Bickerman's interpretation of the events in Jerusalem at the time of Antiochus IV it is not surprising that Bickerman's thesis was not that convincing.

This interpretation finds support in the Seyrig-Robert correspondence in the Fonds Louis Robert. Bickerman and Seyrig were in touch even before the war, as Seyrig had a role in accepting Bickerman's Institutions des Séleucides in the Bibliothèque Archéologique et Historique, under the auspices of the French Antiquities Service of Syria and Lebanon. ${ }^{67}$ Seyrig wrote to Louis Robert on July 25, I938 that he was reading the book and that it was (un) livre remarquable, et pourtant drôlement fait. From I942 until the end of World War II, Seyrig was a special envoy of the Free French Government in New York. He then returned to Beirut. Bickerman and Seyrig met often in New York during the war years, as Seyrig wrote to Robert on September 2I, I944: j’ai souvent parlé de toi avec Bikerman, que je vois très souvent. Seyrig had a keen appreciation of Bickerman's character. He wrote to Robert on September 22, I945 concerning Bickerman: il déteste les indigènes et c'est à Paris qu'il veut être. ${ }^{68}$ Tu as raison c'est un gaffeur ${ }^{69}$ mais c'est un bon professeur et nous avons profit à nous l'attacher. A year later, on November I9, I946, Seyrig wrote to Robert, again about Bickerman:

Bikerman est une des personnes que je regrette le plus d'avoir laissés aux États-Unis. Il avait toujours des choses intéressantes à dire et un jugement très fin, avec une

66 I owe this point to a suggestion of Martha Himmelfarb.

67 Seyrig was appropriately thanked for this role, Bikerman, Institutions des Séleucides. p. 2.

68 On Bickerman's attitude towards the United States and New York see above, n. I2, p. I64, at n. 27, and further Baumgarten, Elias Bickerman, p. I6I-I63. In his letter to Robert of November 23, I945 Bickerman complained about the quality of goods available in the USA: prices were the same as in 1942 (when he first came to NY), but the merchandise was inferior. When cigarettes were in short supply a black market quickly ensued.

One wonders if Bickerman was encouraged to hate New York by his wife and her difficulties there, above, p. I64. In the end, did he blame the United States and New York for the failure of his marriage? Was that part of the explanation for this hatred for the country that had saved him from the horrors of World War II?

69 On the similarities between Bickerman and Nabokov's Pnin, bumbling through a landscape in which he could never be at home, see Baumgarten, Elias Bickerman, p. I56-I58. Even Louis Robert, Bickerman's close personal friend and admirer, thought he was un gaffeur, a blunderer, something of a schlemiel. 
nature agréable - avec des opinions surprenantes, car il aurait vraiment remis sur le trône Nicolas II, prince d'une grande indulgence. ${ }^{70}$

The personal evaluation of Bickerman's character in this letter was far more favorable than in the previous one cited: he was no longer un gaffeur but now avec une nature agréable. However, Bickerman's politics, after his departure from Russia for Berlin in I922, for Paris in I933, and for the USA in I942, were still unchanged, deeply held, and perversely idiosyncratic, even as seen by some of his closest friends and academic admirers. ${ }^{71}$ Therefore, if this political perspective helped provide the lens through which Bickerman saw the persecutions of Antiochus IV, if it blocked his sense of the equivocal nature of his results, which he argued was the case with all historians (above, I74), it is not surprising that other scholars did not follow his lead.

\section{VII}

It would be wrong and do Bickerman a grave injustice to conclude the discussion of Der Gott der Makkabäer on this note. Whether accepting or rejecting his arguments, the thesis Bickerman presented there has proven remarkably provocative and stimulating for more than seventy five years. ${ }^{72}$ This is an achievement that few scholarly works attain. As Grafton noted: "Very few of Bickerman's colleagues are still living presences in research. He is. ${ }^{73 "}$ Perhaps the best way to summarize the discussion of Der Gott der Makkabäer is to cite Morton Smith's evaluation of Goodenough's Jewish Symbols (and even this may be unfair to Bickerman as his Gott der Makkabäer is much more alive in the scholarly discourse than Goodenough's Jewish Symbols): ${ }^{74}$

In the preface to his last volume Goodenough wrote, "Scholars have repeatedly said to me, 'At least you will always be remembered and used for your collection of material'... I have not spent thirty years as a mere collector: I was trying to make a point." He was, and he failed. His pandemic sacramental paganism was a fantasy; so was the interpretation of

70 I understand this remark either as a reflection of the way Bickerman saw Nicholas II or as an ironic comment on the gap between Bickerman's view of Nicholas II and the way others saw the last Tsar of Russia, See his depiction as an incompetent, indecisive, and half-literate rascal, A. Tyrкova-Williams, From Liberty to Brest-Litovsk: The First Year of the Russian Revolution, London I9I9, p.4.

71 Bickerman's politics remained out of step with those current in the liberal university world when at Columbia. See Grafton, "The Bible Scholar", p.37.

72 This is a point on which I am happy to agree with Rappaport, "Elias Bickerman", p. I5o.

73 Grafton, "The Bible Scholar", p.38.

74 I owe this observation to Martha Himmelfarb. 
pagan symbols based on it, and so was the empire-wide, anti-rabbinic, mystical Judaism, based on the interpretation of these symbols. All three are enormous exaggerations of elements which existed, but were rare, in early imperial times.

Soit. Columbus failed, too. But his failure revealed a new world, and so did Goodenough's. ${ }^{75}$

Der Gott der Makkabäer also revealed a new world of the Jews in antiquity and epitomized a new and powerful way of studying it. Der Gott der Makkabäer had highly important favorable consequences that still resonate in the field more than seventy five years later. Few scholars are ever blessed with such glorious "failures."

\author{
Albert I. Baumgarten \\ Bar Ilan University \\ 5 Tsidkiyyahu Street \\ Jerusalem, Israel 93471 \\ albert.baumgarten@biu.ac.il
}

I thank Professor Glen Bowersock of the Institute for Advanced Study, Princeton, responsable du Fonds Louis Robert, for permission to visit the Fonds Louis Robert in May 2012, to examine Bickerman's letters to Robert, and to publish them along with pertinent excerpts from the Seyrig-Robert correspondence. My research at the Fonds Louis Robert was greatly facilitated by the warm welcome and enthusiastic assistance of $\mathrm{M}^{\mathrm{me}}$ Béatrice Meyer, chargée de mission. All citations from letters from Bickerman to Robert and Seyrig to Robert in this article are from the "Archives du Fonds Louis Robert de l'Académie des Inscriptions et Belles-Lettres".

I thank Professor David Kramer, Librarian of the Jewish Theological Seminary, for permission to cite material from Bickerman Archive, ARC I9, in the Jewish Theological Seminary collections. All references to and citations from the Bickerman Archive at the Jewish Theological Seminary in this article appear courtesy of the Archives of the Jewish Theological Seminary Library, New York City. Once again, I acknowledge my debt to Ms. Ellen Kastel, archivist at the Jewish Theological Seminary when I conducted my research there. She was a constant source of inspiration and guidance into the protocols, privileges, and pleasures of archival research. It is thanks to her perceptive diligence that the letters Bickerman saved in his personal copy of Institutions des Séleucides, discussed above, p. I67-ı69, were not lost.

In this paper I elaborate points made in previous publications: A.I. BAumgarten, "Elias Bickerman on the Hellenizing Reformers: A Case Study of an unconvincing case",

75 M. Sмiтн, "Goodenough's Jewish Symbols in Retrospect", Journal of BiblicalLiterature 86 (I967), p. 65-66. 
Jewish Quarterly Review 97 (2007), p. I49-I79; ID., Elias Bickerman as a Historian of the Jews: A Twentieth Century Tale (TSAJ I3I), Tübingen 20I0; ID., "Russian-Jewish Ideas in German Dress: Elias Bickerman on the hellenizing reformers of jewish antiquity", in J.Schulte, O. Taвachnikova, and P.Wagstaff (eds.), The Russian Jewish Diaspora and European Culture (I9I7-1937), Leiden 2012, p.73-I07. In order to keep references to archival material to a minimum I follow the pattern of abbreviations in BAUMgarten, Elias Bickerman, p. 325-332. 